\title{
The incidence of pathogens in honey bee (Apis mellifera L) colonies in Finland and Great Britain
}

\author{
AL Varis 1, BV Ball 2, M Allen 2 \\ 1 University of Helsinki, Department of Agricultural and Forest Zoology, Finland; \\ ${ }^{2}$ AFRC Institute of Arable Crops Research, Department of Entomology and Nematology, \\ Rothamsted Experimental Station, Harpenden, Herts, AL5 2JQ, UK
}

(Received 30 September 1991; accepted 30 December 1991)

\begin{abstract}
Summary - Dead adult bees collected from 26 apiaries distributed throughout Southern Finland were examined for protozoan, microsporidian and viral pathogens. Malpighamoeba mellificae was not found, but Nosema apis was detected at low levels in 11 of the 39 samples examined. Of the 51 samples examined for viruses, bee virus $Y$ was detected in 2, cloudy wing virus in 14 and filamentous virus in 13. These findings are compared with pathogen incidence in honey bee colonies in Britain and discussed with reference to winter losses and Varroa jacobsoni infestation.
\end{abstract}

Apis mellifera / Varroa jacobsoni / Nosema apis / honey bee virus / Finland / Great Britain

\section{INTRODUCTION}

In Finland the winter mortality of honey bee (Apis mellifera L) colonies is currently approximately $15 \%$. There are many reasons for these losses but with the recent spread of the parasitic mite Varroa jacobsoni Oud throughout the mainland of Europe the role of secondary infections, especially viruses, in colony mortality is becoming increasingly apparent.

Previous studies (Ball and Allen, 1988) indicate that $V$ jacobsoni affects the type and prevalence of honey bee virus infections causing mortality. In severely infested colonies in Germany the adult bee and brood population declined sharply at the end of summer, due primarily to acute paralysis virus (APV) infection, and colony mortality was highest in late summer. As little is known of the occurrence of honey bee virus infections in Finland any change in virus incidence associated with the recent establishment there of $V$ jacobsoni would be difficult to identify. The purpose of this study was to investigate the prevalence of pathogens in Finnish colonies in early autumn and by comparison with information from uninfested colonies in Britain, determine if infections could be associated with winter mortality or $V$ jacobsoni infestation. 


\section{MATERIALS AND METHODS}

Dead adult bees were collected during September 1989 from 26 apiaries distributed throughout the primary beekeeping area in Finland. Two samples representing groups of individuals from several colonies were collected from each site, with the exception of one apiary where only one sample was taken. The mean number of colonies per apiary was 9 and the range was from 4 to 30 . The presence of $V$ jacobsoni in each of the apiaries was also noted. Dead bees from 20 colonies in Britain were sampled monthly from 1980 to 1984 inclusive, for the purpose of other studies, and the data on pathogen incidence in September were compared to that in Finland.

Thirty bees from each sample were extracted as described previously (Ball and Allen, 1988) and tested by immunodiffusion against antisera to black queen cell virus (BQCV), bee virus $X(B V X)$, bee virus $Y$ (BVY), chronic paralysis virus (CPV), acute paralysis virus (APV), Kashmir bee virus (KBV), sacbrood virus (SBV), cloudy wing virus (CWV) and deformed wing virus (DWV). The presence of filamentous virus (FV) was determined by observation of the extracts in an electron microscope. The initial clearing pellet of extracts from 39 of the 51 samples from Finland were examined microscopically for protozoa and microspora. Ten individuals from each of the British samples were examined similarly.

\section{RESULTS AND DISCUSSION}

The mean percentage of dead adult bee samples from Britain and Finland in which viruses were detected is shown in figure 1. The incidence of BVY and CWV in samples from colonies in both countries was almost identical, whereas FV was detected in significantly more $(P<0.005)$ of the samples from Finland. Counts of FV particles in the Finnish samples were generally low but the presence of the virus in 13 of the samples from 9 apiaries in 6 different areas indicates the common occurrence and wide distribution of this infection. In

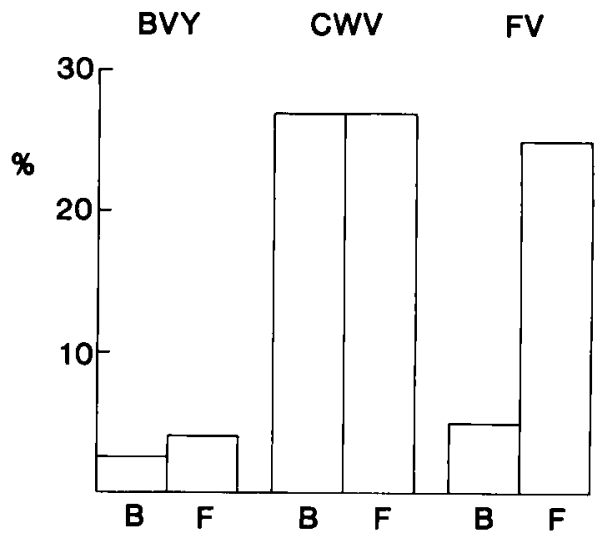

Fig 1. Mean percentage of dead adult bee samples from Britain $(B)$ and Finland $(F)$ in which bee virus (BVY), cloudy wing virus (CWV) and filamentous virus (FV) were detected.

Britain FV is probably the most common and least harmful of all honey bee viruses (Bailey, 1982). It is closely associated with the microsporidian Nosema apis Zander and shows the same regular cycle of annual incidence which peaks in the spring and early summer. Nosema apis was detected in 11 of the 39 Finnish samples examined and approximately half were also infected with FV. Most samples contained few spores but $35 \%$ of apiaries had colonies that were infected. This agrees well with a figure of $33 \%$ of British colonies infected at the same time of year, but an examination of individuals revealed that less that $8 \%$ of the British dead adult bees were infected. Nosema apis infection usually declines spontaneously during late summer, as does FV with which it is associated (Bailey et al, 1983). The honey bee FV thus seems to persist at a low level later in the season in Finland and in association with $N$ apis may contribute to the winter mortality of colonies (Bailey, 1982). 
BVY is another virus which is associated with $N$ apis infection in nature, although it will multiply in the absence of the microsporidian when fed to adult bees in the laboratory. In Britain BVY is also strongly associated with the winter mortality of colonies in combination with $N$ apis (Bailey et al, 1983). However, as the virus was only detected in 2 of the samples from Finland, its low incidence suggests that it is not a major cause of losses there.

CWV infection was equally common in both countries during the sampling period. Previous studies (Bailey et al, 1981) indicated that the incidence of CWV showed no seasonal regularities but that in Britain the virus was significantly associated with the death of colonies (Bailey et al, 1983). The results suggest that CWV may be equally important in both countries as a cause of colony losses.

The only other viruses detected were CPV and BQCV in $1 \%$ of the British samples.

The protozoan parasite Malpighamoeba mellificae Prell was detected in less than $5 \%$ of British colonies during September and less than $1 \%$ of individuals from these colonies were infected. Although $M$ mellificae is significantly associated with BVX in dead bees in late winter and early spring in Britain, there is no similar correlation with colony mortality (Bailey et al, 1983). Malpighamoeba mellificae was not detected in the samples from honey bee colonies in Finland.

Varroa jacobsoni is absent from Britain. The mite was present in 13 apiaries in Finland and the beekeepers assessed infestation levels as high in 2 apiaries, moderate in 4 and low in 7 . There was no correlation between $V$ jacobsoni infestation and virus incidence. In nature adult bees become infected with BVY and FV by ingesting faecal deposits on contaminated combs. These viruses would not therefore be ex- pected to be transmitted by the feeding activities of mites. Laboratory infection experiments with CWV have given equivocal results (Bailey et al, 1980) and $V$ jacobsoni could act as a vector in nature. However, the similar incidence of CWV in Finland and in Britain suggests that the mite is not contributing to virus transmission.

With the exception of FV and $V$ jacobsoni, the incidence of pathogens in honeybee colonies in Finland was similar to that in Britain. The mite does not appear to be influencing the prevalence of secondary infections seen in severely infested colonies elsewhere in Europe (Ball and Allen, 1988). The information will prove useful in future studies as a basis for detecting changes in pathogen incidence in infested colonies.

Résumé - Fréquence des organismes pathogènes dans les colonies d'abeilles (Apis mellifera $L$ ) en Finlande et Grande-Bretagne. En Finlande, la mortalité hivernale des colonies d'abeilles approche couramment $15 \%$. Les causes de ces pertes sont nombreuses mais, avec la propagation récente de Varroa jacobsoni Oud dans la plupart des pays européens, le rôle des infections secondaires, en particulier des viroses, dans la mortalité des colonies est devenu de plus en plus apparent. Étant donné le peu d'informations disponibles sur la présence d'infections virales en Finlande, tout changement dans la fréquence des virus, lié à l'installation récente de $V$ jacobsoni, est difficile à mettre en évidence. Le but de cette étude était de rechercher la fréquence des organismes pathogènes dans les colonies finnoises en début d'automne et, en les comparant avec les données des colonies de GrandeBretagne non infestées par $V$ jacobsoni, de déterminer si ces infections pouvaient être associées à la mortalité hivernale ou à l'infestation par $V$ jacobsoni. 
Cinquante et un échantillons d'abeilles adultes mortes ont été prélevés en septembre dans 26 ruchers d'une région apicole de Finlande. On y a recherché la présence des parasites Nosema apis Zander et Malpighamoeba mellificae Prell par microscopie optique et celle de 10 virus courants d'abeilles par sérologie et microscopie électronique. Chaque mois, de 1980 à 1984 compris, des échantillons d'abeilles mortes ont été prélevés dans 20 colonies de Grande-Bretagne et la fréquence des organismes pathogènes en septembre a été comparée à celle trouvée en Finlande.

On n'a pas trouvé $M$ mellificae mais $N$ apis a été détecté en faible nombre dans 11 des 39 échantillons finnois étudiés. Sur les 51 échantillons examinés pour le virus, le bee virus $\mathrm{Y}(\mathrm{BVY})$, le cloudy wing virus (CWV) et le filamentous virus (FV) ont été détectés dans 2, 14 et 13 échantillons respectivement. $V$ jacobsoni était présent dans 13 des ruchers échantillonnés.

La fréquence des organismes pathogènes dans les colonies d'abeilles a été la même en Finlande et en Grande Bretagne, sauf pour FV et $V$ jacobsoni. FV persiste en faible nombre plus tard en saison en Finlande et pourrait être responsable, en association avec $N$ apis, de la mortalité hivernale des colonies. Aucune corrélation n'a été trouvée entre l'infestation par $V$ jacobsoni et la fréquence des virus. L'acarien ne semble donc pas avoir d'influence sur la fréquence des infections secondaires telles qu'elles ont été observées ailleurs en Europe dans des colonies d'abeilles fortement infestées. Cette information sera utile dans d'autres études comme base pour détecter des changements dans la fréquence des organismes pathogènes dans les colonies infestées.

Apis mellifera / Varroa jacobsoni / Nosema apis / virus / Finlande / GrandeBretagne
Zusammenfassung - Vorkommen von Pathogenen in Bienenvölkern (Apis mellifera $L$ ) in Finnland und Großbritannien. In Finnland beträgt die durchschnittliche Wintermortalität der Honigbiene ungefähr $15 \%$. Es gibt viele Ursachen für diese Verluste. Mit der jüngsten Ausbreitung der Varroa-Milbe (Varroa jacobsoni Oud) wird in den meisten europäischen Ländern der Anteil sekundärer Infektionen an der Mortalität der Bienen immer deutlicher. Das gilt besonders für Viren. Bisher gibt es in Finnland nur wenige Angaben über das Auftreten von Bienenviren. Dadurch wäre jede Veränderung im Vorkommen der Viren, die durch die jüngste Einschleppung von $V$ jacobsoni entsteht, schwierig zu erkennen. Das Ziel der vorliegenden Arbeit war, die gegenwärtige Verbreitung von Pathogenen in den finnischen Bienenvölkern im Frühherbst zu untersuchen. Durch Vergleich dieser Angaben mit den Daten von nicht durch Varroa infizierten Völkern in Großbritannien sollte bestimmt werden, ob die Infektionen mit der Wintermortalität oder mit dem Befall durch $V$ jacobsoni in Zusammenhang stehen. 51 Proben von toten, adulten Bienen wurden im September aus 26 Bienenständen in Südfinnland entnommen. Sie wurden auf die Parasiten Nosema apis Zander und Malpighamoeba mellificae Prell mikroskopisch und auf zehn allgemein auftretende Bienenviren serologisch oder elektronenmikroskopisch untersucht. Tote Bienen aus 20 Völkern von Großbritannien wurden in den Jahren 1980-1984 gesammelt. Das Vorkommen von Pathogenen im September wurde mit dem entsprechenden Vorkommen in Finnland verglichen. In den finnischen Proben wurde Malpighamoeba mellificae nicht gefunden, aber bei 11 von 39 Proben wurde eine leichte Infektion durch Nosema apis nachgewiesen. Von den 51 auf Viren untersuchten Proben wurde das Bienen-Virus $Y$ (BVY) in zwei, das Opakflügel-Virus 
(CWV) in 14 und das Faden-Virus (FV) in 13 Proben gefunden. $V$ jacobsoni trat bei 13 der untersuchten Bienenstände auf. Mit Ausnahme von FV und $V$ jacobsoni war das Vorkommen von Pathogenen in Finnland und Großbritannien ähnlich. FV bleibt auf einem niedrigen Infektions grad bis in die späte Saison in Finnland bestehen und mag im Zusammenhang mit $N$ apis zur Wintermortalität der Bienenvölker beitragen. Es wurde keine Korrelation zwischen der $V$ jacobsoni-Infektion und dem Auftreten von Viren festgestelit. Damit scheint die Milbe das Auftreten von sekundären Infektionen in Finnland nicht $\mathrm{zu}$ beeinflussen, wie es anderswo in Europa bei hoch infizierten Völkern beschrieben ist. Diese Information wird sich in künftigen Studien als Grundlage für die Ermittlung der Veränderungen in von Verbreitung von Pathogenen in infizierten Bienenvölkern als nützlich erweisen.
Apis mellifera / Varroa jacobsoni I Nosema apis / Bienenviren / Finnland / Großbritannien

\section{REFERENCES}

Bailey L (1982) Viruses of honeybees. Bee World 63, 165-173

Bailey L, Ball BV, Carpenter JM, Woods RD (1980) Small virus-like particles in honey bees associated with chronic paralysis virus and with a previously undescribed disease. $J$ Gen Virol 46, 149-155

Bailey L, Ball BV, Perry JN (1981) The prevalence of viruses of honey bees in Britain. Ann Appl Biol 97, 109-118

Bailey L, Ball BV, Perry JN (1983) Association of viruses with two protozoal pathogens of the honey bee. Ann Appl Biol 103, 13-20

Ball BV, Allen MF (1988) The prevalence of pathogens in honey bee (Apis mellifera) colonies infested with the parasitic mite Varroa jacobsoni. Ann Appl Biol 113, 237-244 